\title{
KOMUNIKASI MATEMATIK DALAM PEMBELAJARAN PROGRAM LINIER BERKARAKTERISTIK KEWIRAUSAHAAN UNTUK MENUMBUHKAN JIWA WIRAUSAHA MAHASISWA PENDIDIKAN MATEMATIKA
}

\author{
Retno Marsitin \\ Program Studi Pendidikan Matematika Universitas Kanjuruhan Malang \\ mars.ayuu@gmail.com
}

\begin{abstract}
This study aims to describe the implementation of mathematical communication skills in teaching linear program with entrepreneurial characteristic to foster the entrepreneurial spirit in students of mathematics education. This study used a qualitative approach, with a type of research is classroom action research, which was conducted in two cycles. Subject of this research is students of mathematics education who take a course in linear program with the total of 25 students. Data were collected through observation, testing, documentation, and field notes. Data were analyzed from early action learning and reflection made up statements. Data analysis techniques used in this research is descriptive qualitative data analysis that includes data reduction, data presentation, analyzing data and drawing conclusions (verification). The validity of the data use triangulation techniques. The results showed that an improvement in mathematical communication skills and foster an entrepreneurial spirit of student in the learning of linear program. This is showed by the data obtained on students' academic ability success of $76 \%$, the ability of mathematical communications with achievement of $82,33 \%$ and students' entrepreneurial spirit achieved $79,67 \%$.
\end{abstract}

Keywords: mathematical communication, entrepreneurial spirit, linear program

\section{PENDAHULUAN}

Salah satu indikator kualitas pendidikan dapat dilihat dari mutu lulusan, dimana mutu lulusan tersebut dipengaruhi oleh input yang dimiliki yaitu sumber daya manusia, proses pembelajaran dan output yaitu hasilnya sesuai dengan tujuan yang diharapkan. Dalam meningkatkan kualitas pendidikan diperlukan perbaikan pembelajaran yang mampu mendorong pembentukan kompetensi mahasiswa di perguruan tinggi, terutama peningkatan kualitas pembelajaran pada program studi pendidikan matematika di Universitas Kanjuruhan Malang.

Peningkatan kualitas pembelajaran sangat bergantung dari kualitas dosen dan kesesuaian strategi mengajar dalam pembelajaran.Dosen sebagai manajer pembelajaran harus aktif juga kreatif dalam mengelola pembelajaran. Proses pembelajaran merupakan salah satu aktivitas pembelajaran dan dosen diharapkan bisa menciptakan suasana pembelajaran yang melibatkan mahasiswa secara aktif agar kualitasnya lebih baik. Rendahnya kemampuan mahasiswa dalam penguasaan materi matematika diantaranya karena kemampuan dasar mahasiswa, motivasi belajar mahasiswa, strategi pembelajaran yang diterapkan dosen, media pembelajaran yang digunakan dosen, dan sebagainya. Faktor-faktor tersebut secara langsung berpengaruh terhadap proses pembelajaran (Sardiman AM, 2005). Pembelajaran perlu dikemas lebih menantang agar secara produktif dapat mengembangkan potensi mahasiswa sebagai subyek didik yaitu pembelajaran kooperatif.

Pembelajaran kooperatif merupakan model pembelajaran dengan pengelompokan dan teknikteknik kelas yang praktis yang dapat digunakan dosen untuk membantu mahasiswa dalam proses 
belajar mengajar setiap matakuliah, mulai dari ketrampilan-ketrampilan dasar sampai pemecahana masalah serta penyelesaian masalah dalam matematika. Pembelajaran matematika merupakan kegiatan belajar dalam matematika yang mengandung arti belajar (berpikir). Untuk itu, mahasiswa diharapkan mampu berpikir dan bernalar dalam memahami konsep-konsep dalam matematika yang abstrak. Berawal dari kemampuan mahasiswa berkomunikasi matematik maka mahasiswa mampu merubah permasalahan program linier yang cenderung dalam soal cerita ke dalam model matematik, mampu menyelesaikan dan memecahkan setiap problem matematika. Hal ini, sesuai dengan penelitian Karlimah (2010), bahwa kesulitan yang dialami mahasiswa dalam menyelesaikan masalah komunikasi matematis adalah dalam menyatakan suatu uraian atau paragraf matematis ke dalam gambar matematis, dan menunjukkan algoritma matematis dalam menyelesaikan masalah, serta kemampuan menginterpretasikan hasil yang sesuai permasalahan asal. Mahasiswa diharapkan termotivasi dalam dunia usaha dan tercipta daya pikir yang kreatif dan inovatif dalam berwirausaha serta lebih mudah memahami permasalahan matematika program linier. Bekenaan dengan hal itu, permasalahan matematika pada program linier diupayakan untuk dikaitkan dengan kehidupan, terutama difokuskan pada kehidupan dunia usaha (berkarakteristik kewirausahaan) melalui kemampuan komunikasi matematik. Salah satu upaya agar tercapai standard kompetensi matakuliah program linier maka peneliti melakukan inovasi pembelajaran matematika dengan mengembangkan kemampuan komunikasi matematik dalam pembelajaran program linier berkarakteristik kewirausahaan untuk menumbuhkan jiwa wirausaha pada mahasiswa program studi pendidikan matematika. Adapun tujuan penelitian yaitu untuk mendiskripsikan implementasi kemampuan komunikasi matematik dalam pembelajaran program linier berkarakteristik kewirausahaan untuk menumbuhkan jiwa wirausaha pada mahasiswa program studi pendidikan matematika.

\section{KAJIAN TEORI \\ Pembelajaran Matematika}

Pembelajaran merupakan proses interaksi antara dua manusia yaitu pembelajar sebagai pihak yang belajar dan pembelajar sebagai pihak yang mengkondisikan terjadinya kegiatan belajar (Yamin, 2004; Sardiman A.M, 2005). Matematika merupakan ilmu pengetahuan eksak yang terorganisir secara sistematis, terstruktur serta menggunakan aturan-aturan serta menggunakan aturan-aturan yang ketat dengan mengungkap beberapa fakta kuantitatif dan masalah tentang ruang dan bentuk (R. Soedjadi, 2000). Pembelajaran matematika merupakan kegiatan belajar dalam matematika yang mengandung arti belajar (berpikir). Untuk itu, mahasiswa diharapkan mampu berpikir dan bernalar dalam memahami konsep-konsep dalam matematika yang abstrak. Salah satu model pembelajaran matematik yang sesuai yaitu pembelajaran kooperatif dengan membagi mahasiswa dalam kelompok dengan kemampuan akademik yang heterogen. Beberapa keuntungan yang diperoleh dari pembelajaran kooperatif (cooperative learning), yaitu (a) mengurangi kecemasan (reduction of anxiety), (b) belajar melalui kumunikasi (learning through cummunication), (c) data berdiskusi (discuss), adu gagasan (wrestle with idea), konsep dan keahlian sampai benar-benar memahaminya, (d) memiliki rasa peduli (care), rasa tanggung jawab (take responsibility) terhadap teman lain dalam proses belajarnya, (e) belajar menghargai (learn to appreciate), perbedaan etnik (ethnicity), perbedaan tingkat kemampuan (performance leverl) dan cacat fisik (disability). Adapun kelemahan dari aktivitas pembelajaran kooperatif (cooperative learning), diantaranya (a) terhambatnya cara berpikir peserta didik yang mempunyai emampuan lebh terhadap peserta didik yang kurang, (b) memerlukan waktu yang lama, (c) apa yang dipelajari dan dipahami belum seluruhnya dicapai oleh peserta didik, (d) penilaian yang diberikan bukanlah nilai elompok melainkan nilai atau hasil dari prestasi setiap individu (Anita, 2002; Wina, 2008).

\section{Desain Komunikasi dalam Pembelajaran}

Pembelajaran merupakan terjalinnya komunikasi yang terencana untuk tercapainya tujuan yang telah ditetapkan. Lestari G (2003), menjelaskan bahwa ada beberapa faktor yang perlu dipahami dalam membangun komunikasi yaitu kejelasan, ketepatan, konteks (situasi), alur dan budaya. Selain itu, pembelajaran dapat tersampaikan dengan baik pada mahasiswa dengan memperhatikan beberapa aspek, diantaranya: (a) Kesiapan dan motivasi, yaitu mencakup kesipaan mental dan fisik, misalnya memberikan pretes, deskripsi tentang keuntungan kerugian dari pembelajaran yang disampaikan; (b) Alat Penarik Perhatian, yaitu dosen harus pandai membuat daya tarik untuk mengendalikan perhatian 
mahasiswa pada saat belajar, misalnya memberikan ilustrasi verbal dan visual, humor, dan lain sebagainya; (c) Partisipasi Aktif Siswa, yaitu dosen harus berusaha membuat mahasiswa aktif dalam proses pembelajaran, misalnya tanya jawab, drill, praktik latihan, kritik komentar, dan lain sebagainya; (d) Pengulangan, yaitu penyampaian materi sebaiknya dilakukan berulang kali, misalnya preview agar mahasiswa dapat menerima dan memahami materi dengan baik; (e) Umpan Balik, yaitu dosen memberikan umpan balik atau feedback sebagai pemicu semangat bagi mahasiswa, misalnya berupa penguatan terhadap jawaban yang benar, meluruskan jawaban yang salah, memberi komentar terhadap hasil kerja mahasiswa, dan lain sebagainya; (f) Menghindari materi yang tidak relevan, yaitu dosen sedapat mungkin menghindari materi-materi yang tidak relevan dengan topik yang dibicarakan agar tidak menimbulkan kebingungan atau bias dalam pemahaman mahasiswa.

Komunikasi yang efektif jika mengandung aliran informasi dari dua arah yaitu antara komunikator dan komunikan. Informasi tersebut direspon bersama-sama sesuai dengan harapan keduanya yang meliputi lima aspek, yaitu: (a) Kejelasan, yaitu dalam komunikasi harus menggunakan bahasa dan mengemas informasi secara jelas, sehingga mudah diterima dan dipahami oleh komunikan; (b) Ketepatan, yaitu secara tepat dan akurat menyangkut penggunaan bahasa yang benar dan kebenaran informasi yang disampaikan; (c) Konteks, yaitu bahasa dan informasi yang disampaikan harus sesuai dengan keadaan dan lingkungan dimana komunikasi itu terjadi; (d) Alur, yaitu bahasa ataupun informasi yang disajikan harus disusun sesuai alur atau sistematika yang jelas, sehingga yang menerima informasi cepat tanggap; (e) Budaya, yaitu aspek bahasa dan informasi yang berkaitan dengan tatakrama dan etika, berarti dalam berkomunikasi harus menyesuaikan dengan budaya orang yang diajak berkomunikasi, baik dalam penggunaan bahasa verbal maupun non verbal, agar tidak menimbulkan kesalahan persepsi (Lestari G, 2003; Wardani, 2005)

\section{Kemampuan Komunikasi Matematik}

Matematika merupakan suatu bahasa dan bahasa tersebut sebagai bahasa terbaik dalam komunitasnya, maka mudah dipahami bahwqa komunikasi merupakan esensi dari mengajar, belajar dan meng-assess matematika. Komunikasi matematik dalam pembelajaran matematika memegang peranan yang sangat penting. Komunikasi menjadi bagian yang esensial dari matematika dan pendidikan matematika. Komunikasi merupakan cara dalam berbagi (sharing) gagasan dan mengklarifikasi pemahaman. Melalui komunikasi, gagasan-gagasan menjadi objek-objek refleksi, penghalusan, diskusi, dan perombakan. Proses komunikasi juga membantu membangun makna dan kelanggengan untuk gagasan-gagasan, serta juga menjadikan gagasan-gagasan itu diketahui publik (NCTM, 2000). Komunikasi matematika membantu dosen dalam memahami kemampuan mahasiswa untuk mengintrepretasikan dan mengekspresikan konsep-konsep matematika pada proses pembelajaran matematika. Berbagai sumber juga menyebutkan tentang peran penting komunikasi dalam pembelajaran matematika (Pugalee \& Knuth, 2001).

Silver, Kilpatrick \& Schlesinfer (NCTM, 2000) berpendapat bahwa komunikasi dapat mendukung pembelajaran mahasiswa dalam menemukan konsep matematika yang baru, misalnya mereka memahami sesuatu, menggambarkan, menggunakan benda, memberikan perhitungan secara jelas serta menjelaskan, menggunakan diagram, menuliskan dan menggunakan simbol matematika. Lang \& Evans (2006) berpendapat bahwa seorang dosen perlu menjadi komunikator yang efektif. Kauchak dan Eggen (Lang \& Evans, 2006) menyatakan bahwa komponen komunikasi yang efektif yaitu: istilah yang tepat, percakapan yang nyambung, isyarat untuk transisi, penekanan dan kesesuaian antara tindak-tanduk verbal dan nonverbal. Seorang dosen matematika haruslah mampu mengkomunikasikan pikiran matematiknya secara lisan dan tertulis kepada teman-temannya, para dosen dan kepada yang lainnya dengan indikator yaitu: (a) mampu mengkomunikasikan pikiran matematiknya secara koheren dan jelas kepada teman-temannya, para dosen, dan kepada yang lainnya, (b) mampu menggunakan bahasa matematika untuk mengekspresikan ide atau gagasan secara tepat, (c) mampu mengelola pikiran matematiknya melalui komunikasi; (d) mampu menganalisis dan mengevaluasi matematik dan strategus-strategi orang lain (NCTM, 2003; Yani Ramdhani, 2012). Mahasiswa sangat perlu mengembangkan kemampuan komunikasi matematik sehingga mahasiwa mampu merubah permasalahan program linier dalam model matematik dan menyelesaikan dengan cermat dan teliti. 


\section{Berkarakteristik Kewirausahaan}

Kewirausahaan dalam dunia pendidikan adalah seorang individu yang berani mengembangkan usaha mapun ide barunya untuk memperbaiki kualitas hidup yang diintegratisikan dalam pendidikan melalui pembelajaran yang diintegrasikan dalam kewirausahaan dan kewirausahaan merupakan disiplin ilmu tersendiri karena berisi body of knowledge yang utuh dan nyata karena ada obyek, konsep dan metodenya (Suryana, 2001; Karli, 2012). Matematika merupakan ilmu pengetahuan yang memilikian peranan penting dalam dunia pendidikan dan kehidupan. Salah satu karakteristik matematika yaitu diterapkan ataupun diaplikasikan dalam bidang ilmu lain maupuan dalam realita kehidupan. Perkembangan ilmu pengetahuan dan teknologi tidak lepas dari peranan matematika, diantaranya yaitu kewirausahaan. Kewirausahaan merupakan salah satu dari ilmu selain matematika, tetapi ilmu matematika mempunyai kaitan dengan bidang kewirusahaan terutama dalam pembelajaran matematika. Pembelajaran matematika sudah seharusnya memberikan karakteristik kewirausahaan, karena matematika berperan penting dalam dunia wirausaha. Hal ini tidaklah mudah untuk direalisasikan. Y. Marpaung (2010: 31) berpendapat bahwa tidak mudah merumuskan kompetensi yang cocok mengenai kewirausahaan melalui pembelajaran matematika, tetapi melalui pembelajaran matematika dengan melakukan diskusi dapat ditumbuhkembangkan sikap berwirausaha dalam diri siswa serta perlu dikembangkan dan diedarkan model pembelajaran yang dapat mengembangkan sikap berwirausaha pada mahasiswa.

\section{Wirausaha}

Baumassepe (2001) menyatakan bahwa mahasiswa lebih baik memiliki pola pikir sebagai wirausaha dan saatnya mahasiswa mempunyai tantangan untuk menjadi agent of change dalam bidang dunia usaha maupun bidang kehidupan yang lain. Pemikiran yang kreatif dan inovatif harus dikembangkan mahasiswa agar tercipta lapangan kerja baru dalam dunia usaha. Pembelajaran program linier berkarakteristik kewirausahaan dengan memiliki kemampuan komunikasi matematik diharapkan menumbuhkan keinginan mahasiswa untuk wirausaha dalam dunia usaha. Meredith (2005) berpendapat bahwa wirausaha yaitu orang-orang yang mempunyai kemampuan melihat dan menilai kesempatan usaha mengumpulkan sumber daya yang dibutuhkan guna mengambil keuntungan daripadanya dan mengambil tindakan yang tepat guna memastikan kesukseskan. Adapun ciri dan watak kewirausahaan terlihat dalam tabel berikut:

Tabel 1. Ciri dan watak kewirausahaan

\begin{tabular}{cll}
\hline No & \multicolumn{1}{c}{ Ciri-ciri } & \multicolumn{1}{c}{ Watak } \\
\hline 1 & Percaya diri & $\begin{array}{l}\text { Keyakinan, ketergantungan, individualis dan optiomis } \\
\text { Kebutuhan untuk berprestasi, berorientasi laba, } \\
\text { ketekunan dan ketabahan, tekad kerja keras, } \\
\text { mempunyai dorongan kuat, energetik dan inisiatif }\end{array}$ \\
2 & $\begin{array}{l}\text { Berorientasi pada tugas dan } \\
\text { hasil }\end{array}$ & $\begin{array}{l}\text { Kemampuan untuk mengambil resiko yang wajar dan } \\
\text { suka tantangan }\end{array}$ \\
3 & Pengambilan Resiko & $\begin{array}{l}\text { Perilaku sebagai pimpinan, bergaul dengan orang lain } \\
\text { menanggapi sarand an kritik }\end{array}$ \\
4 & Kepemimpinan & $\begin{array}{l}\text { Inovatif dan kreatif serta fleksibel } \\
\text { Pandangan ke depan, prespektif }\end{array}$ \\
5 & Keorisinalan &
\end{tabular}

Kegiatan pembelajaran dalam setiap matakuliah bisa dikembangkan, diintegrasikan, dikaitkan dengan jiwa wirausaha yang disesuiakan dengan konteks kehidupan realita, sehingga tumbuh jiwa wirausaha dalam diri mahasiswa. Indikator jiwa wirausaha yang bisa dikembangkan yaitu: percaya diri dikembangkan melalui keberanian; berorientasi pada tugas dikembangkan melalui hasil dan disiplin; pengambilan resiko dikembangkan melalui pantang menyerah; kepemimpinan dikembangkan melalui mandiri komunikatif dan bertanggungjawab; keorisinalan dikembangkan melalui jujur, kreatif dan inovatif; berorientasi ke masa depan dikembangkan dengan menyampaikan gagasan. Suderajat (2011), ada dua cara yang bisa dijalankan dalam menumbuhkan karakter termasuk jiwa kewirausahaan. Cara pertama, dengan melatih dan membiasakan perilaku sesuai dengan nilai-nilai, yang berarti dipaksa untuk berperilaku sesuai dengan norma-norma akhlak mulia, sehingga diharapkan agar terbiasa berperilaku dengan akhlak mulia. Cara kedua, dengan meningkatkan 
kecerdasan melalui pemahaman atas akhlak-akhlak mulia, sehingga nilai tersebut dapat diterima dalam dirinya, diintegrasikan dalam penghayatan. Kecerdasan tinggi yang dimilikinya, mampu menganalisis dan mengevaluasi konsep dengan baik sehingga pola pikir dalam dirinya memiliki wawasan yang luas.

\section{Program Linier}

Program linier merupakan salah satu matakuliah dalam program studi pendidikan matematika, yang wajib ditempuh dengan beban 3 sks. Dalam deskripsi matakuliah termuat standard kompetensi matakuliah program linier yaitu mahasiswa memahami dan menguasai konsep-konsep dalam program linear dan mampu menerapkan. Permasalahan dalam program linier cenderung dalam bentuk soal cerita yang sangat memerlukan kemampuan mahasiswa dalam berkomunikasi matematik, sehingga mahasiswa mampu merubah soal cerita dalam model matematik. Soal cerita dalam program linier diupayakan berkarakteristik kewirausahaan sesuai agar mahasiswa termotivasi dalam dunia usaha dan lebih memahami permasalahan yang dihadapi serta mampu menyelesiakannya dengan baik dan benar. Untuk itu, agar tercapai standard kompetensi matakuliah program linier maka peneliti melakukan inovasi pembelajaran matematika dengan berupaya mengembangkan kemampuan komunikasi matematik dalam pembelajaran program linier berkarakteristik kewirausahaan untuk menumbuhkan jiwa wirausaha pada mahasiswa program studi pendidikan matematika.

\section{METODE PENELITIAN}

Penelitian ini menggunakan pendekatan kualitatifdengan pembahasan secara diskriptif kunatitaif. Jenis penelitiannya yaitu Penelitian Tindakan Kelas (PTK) atau Classroom Action Research. Kegiatan penelitian berangkat dari permasalahan riil yang dihadapi oleh peneliti dalam tugas pokok dan fungsinya, kemudian direfleksikan alternatif pemecahan masalahnya dan ditindaklanjuti dengan tindakan-tindakan nyata yang terencana dan terukur (Sukmadinata, 2011; Sugiyono, 2011; Sutama, 2011). Penelitian ini dilakukan di Progam Studi Pendidikan Matematika Universitas Kanjuruhan Malang dengan subyek penelitian yaitu mahasiswa program studi Pendidikan Matematika yang menempuh matakuliah program linier yang berjumlah 25 mahasiswa. Pengambilan data meliputi: (a) observasi, yaitu mengumpulkan data dengan pengamatan terhadap pembelajaran yang berlangsung; (b) tes, yaitu rangkaian pertanyaan (soal) untuk mengukur keterampilan, pengetahuan, intelegensi, kemampuan, atau bakat yang dimiliki oleh individu atau kelompok; (c) dokumentasi, yaitu pengumpulan data melalui dokumen, (d) catatan lapangan, yaitu mencatat peristiwa dan pengalaman penting yang terjadi selama pembelajaran berlangsung (Sukmadinata, 2011; Sugiyono, 2011; Mahmud, 2011). Instrumen penelitian dikembangkan dengan validitas isi oleh dosen senior pendidikan matematika. Data dianalisis mulai awal tindakan pembelajaran dan dilakukan refleksi hingga penyusunan laporan. Teknik analisis data yang digunakan dalam penelitian ini adalah analisis data kualitatif deskriptif yang meliputi reduksi data, penyajian data, menelaah data dan penarikan kesimpulan (verifikasi). Keabsahan data dengan menggunakan teknik triangulasi yaitu teknik pemeriksaan keabsahan data untuk pengecekan dan sebagai pembanding terhadap data tersebut (Moleong, 2008). Penyajian data dilakukan untuk pemahaman terhadap segala informasi yang memberikan adanya penarikan kesimpulan dan verifikasi data untuk memperoleh derajat kepercayaan yang tinggi.

\section{HASIL DAN PEMBAHASAN \\ Hasil Penelitian}

Hasil Penelitian implementasi pengembangan kemampuan komunikasi matematik dalam pembelajaran program linier berkarakteristik kewirausahaan untuk menumbuhkan jiwa wirausaha pada mahasiswa program studi pendidikan matematika, diperoleh data pada sikulus I meliputi: (a) aktivitas peneliti sebagai tenaga pendidik pada pembelajaran dari kedua observer diperoleh presentase skor rata-rata yaitu $68.75 \%$ dari observer I, sedangkan dari observer II dengan presentase nilai skor yaitu 69.38\%; (b) aktivitas mahasiswa pada pembelajaran dari kedua observer presentase skor ratarata yaitu $66.15 \%$ dari observer I, sedangkan dari observer II dengan presentase nilai skor yaitu $63.46 \%$; (c) pengembangan komunikasi matematik dengan ketercapaian $56.25 \%$; (d) jiwa wirausaha 
dalam diri mahasiswa dengan ketercapaian 54.67\%; (e) presentasi mahasiswa dengan ketercapaian $56 \%$; (f) hasil kemampuan akademik mahasiswa dengan skor $\geq 75$ mencapai $64 \%$.

Pada sikulus II diperoleh data hasil penelitian yang meliputi: (a) aktivitas peneliti sebagai tenaga pendidik pada pembelajaran dari kedua observer diperoleh presentase skor rata-rata yaitu $82.81 \%$ dari observer I, sedangkan dari observer II dengan presentase nilai skor yaitu $84.89 \%$; (b) aktivitas mahasiswa pada pembelajaran dari kedua observer presentase skor rata-rata yaitu $84.23 \%$ dari observer I, sedangkan dari observer II dengan presentase nilai skor yaitu $83.85 \%$; (c) pengembangan komunikasi matematik dengan ketercapaian 82.33\%; (d) jiwa wirausaha dalam diri mahasiswa dengan ketercapaian 79.67\%; (e) presentasi mahasiswa dengan ketercapaian 88\%; (f) hasil kemampuan akademik mahasiswa dengan skor $\geq 75$ mencapai $76 \%$.

Selain itu, angket respon mahasiswa terhadap pembelajaran linear dalam penelitian menunjukan hasil yang positif dengan ketercapaian $83.47 \%$. Angket respon dilaksanakan di siklus akhir, untuk mengetahui antusias mahasiswa terhapa proses pembelajaran dalam perkuliahan. Adapun hasil ketercapaian dalam penelitian tampak dalam tabel dan gambar berikut:

Tabel 2. Hasil Ketercapaian dalam Penelitian

\begin{tabular}{clcc}
\hline No & Uraian & Siklus I & Siklus II \\
\hline 1 & Observasi Aktivitas Peneliti (Dosen) & $69.06 \%$ & $83.75 \%$ \\
2 & Observasi Aktivitas Mahasiswa & $64.81 \%$ & $84.04 \%$ \\
3 & Komunikasi Matematik & $56.25 \%$ & $82.33 \%$ \\
4 & Jiwa Wirausaha & $54.67 \%$ & $79.67 \%$ \\
5 & Presentasi Mahasiswa & $56 \%$ & $88 \%$ \\
6 & Kemampuan Akademik Mahasiswa & $64 \%$ & $76 \%$ \\
\hline
\end{tabular}

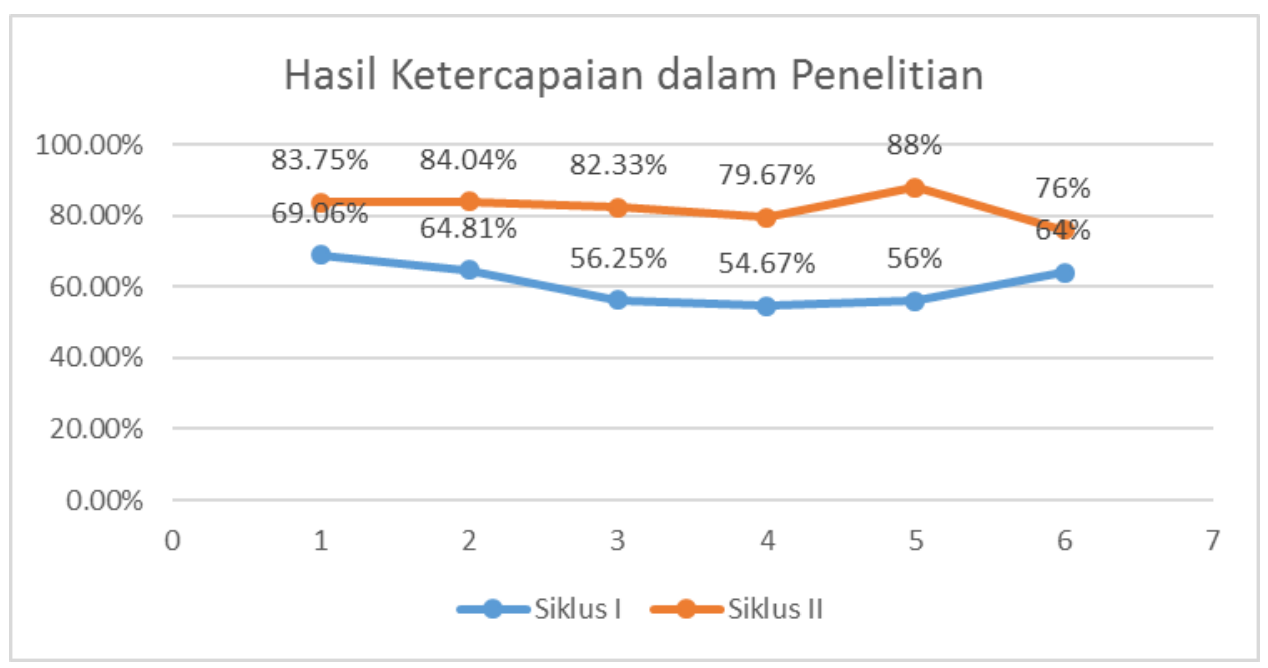

Gambar 1. Hasil Ketercapaian dalam penelitian

\section{Pembahasan Penelitian}

Hasil penelitian diatas dapat dikatakan bahwa terjadi peningkatan ketercapaian yang diperoleh dalam siklus dua yang tampak dari hasil observasi baik dalam observasi aktivitas tenaga pendidik (dosen) maupun observasi aktivitas mahasiswa. Keterlibatan mahasiswa dalam pembelajaran merupakan salah satu aktivitas pembelajaran yang berpusat pada mahasiswa. Pembelajaran matematika tidak sekedar hanya memahami konsep teori saja tetapi bisa dikembangkan dengan melibatkan mahasiswa dalam aktivitas pembelajaran. Hal ini, sejalan dengan pendapat Purnawan (2007), yang menyatakan bahwa pembelajaran matematika tidak hanya memberikan konsep teori yang cukup saja tetapi juga memberikan contoh-contoh pemecahan secara realita dengan memanfaatkan strategi pembelajaran yang mendukung ketercapaian pembelajaran yang maksimal, sehingga pembelajaran berfokus pada konsep-konsep dan prinsip-prinsip inti yang melibatkan mahasiswa dalam investigasi pemecahan masalah dan kegiatan tugas-tugas bermakna yang lain, 
memberi kesempatan mahasiswa bekerja secara otonom mengkonstruk pengetahuan mereka sendiri, dan mencapai puncaknya menghasilkan produk nyata. Kemampuan mahasiswa secara akademik dan keberanian mahasiswa dalam presentasi juga mengalami peningkatan ketercapaiannya pada siklus kedua. Hal ini, sejalan dengan pendapat Ramsden (2006), Biggs (2006), Amin \& Eng (2006) yang menyatakanbahwa ada tiga teori pengajaran berdasarkan keaktifan mahasiswa dan cara pandang dosen dalam memahami konsep pengajaran, yaitu mengajar merupakan memindahkan pengetahuan kepada mahasiswa, mengajar haruslah disertai dengan usaha mengaktifkan mahasiswa dan mengajar haruslah mengaktifkan mahasiswa dengan fokus terhadap proses belajar yang harus benar-benar bermakna juga efektif. Selain itu, Asma (2006:78) juga berpendapat bahwa untuk tahap presentasi maka yang dilakukan yaitu masing-masing kelompok mempresentasikan hasil kerja kelompoknya, dosen menunjuk seorang dari kelompok yang tidak sedang melakukan presentasi sebagai pengatur waktu, pengatur waktu memberikan peringatan ketika waktunya sudah mendekati habis, misalnya waktu tinggal sepuluh menit, anggota kelompok mungkin ingin memasukkan waktu untuk tanya jawab dan atau waktu untuk memberikan komentar dan umpan balik ke dalam presentasinya.

Pembelajaran program linier dalam penelitian ini dengan memberikan soal-soal cerita pada lembar kerja mahasiswa yang dikaitkan dengan jiwa kewirausahakan sebagai upaya dalam menumbuhkan jiwa wirausahaan dalam diri mahasiswa, sejalan dengan pendapat Baumassepe (2001), yang menyatakan bahwa sangat masuk akal bagi mahasiswa (dengan atribut-atribut yang dimilikinya) agar memiliki pola pikir sebagai seorang wirausahawan dalam dirinya. Kemampuan tumbuhnya jiwa wirausaha ada peningkatan dalam diri mahasiswa, yang juga didukung dengan ketercapaian dalam kemampuan komunikasi matematik yang dimilikinya. Hal ini, sesuai dengan Patricia (2000) berpendapat bahwa guru dapat mempercepat peningkatan komunikasi matematika dan penalaran siswa dengan langkah memberikan soal matematika dalam berbagai variasi. Untuk itu, dapat dikatakan bahwa membangun kemampuan komunikasi bagi pendidik adalah sebagai "teaching how to learn mathematics", sedangkan bagi mahasiswa bermakna sebagai "learning how to learn mathematics" (Jacob, 2003).

\section{PENUTUP}

Kesimpulan yang dapat diberikan pada penelitian ini diantaranya yaitu kemampuan komukasi matematik mahasiswa pada pembelajaran materi terlihat dalam menyelesaikan permasalahan program linier, sehingga jiwa wirausaha ada dalam diri mahasiswa. Mahasiswa yang memiliki jiwa wirausaha lebih mudah dalam memahani soal cerita dalam permasalahan program linier dan mahasiswa lebih mudah mengembangkan komunikasi matematiknya dalam menyelesaiakannya permasalahan tersebut. Adapun saran yang dapat diberikan pada penelitian ini yaitu pada penelitian selanjutnya berkenan dan berminat mengimplementasikan pembelajaran komunikasi matematik dalam menumbuhkan jiwa wirausaha lebih berinovasi dengan mengembangkan karakteristik mahasiswa dan kecakapan dalam matematika, sehingga lebih variatif dalam veriabel penelitian dan pembelajaran matematika lebih berkualitas.

\section{DAFTAR RUJUKAN}

Amin, Z. \& Eng, K.H. 2006. Basics in Medical Education. Singapore: World Scientific Publishing Co. Pte.Ltd.

Anita Lie. 2002. Cooperative Learning (Mempraktikan Cooperative Learning di Ruang-ruang Kelas). Jakarta: PT. Gramedia Widiasarana Indonesia.

Asma, Nur. 2006. Model Pembelajaran Kooperatif. Jakarta: Departemen Pendidikan Nasional Direktorat Jenderal Pendidikan tinggi Direktorat Ketenagaan

Baumassepe, Andi Nur. 2001. Berwirausaha Sejak Mahasiswa. Makalah. Yogyakarta: STIE YKPN.

Biggs, J. 2006. Teaching for Quality Learning at University. $2^{\text {nd }}$ ed. SRHE and Open University Press Imprint.

Jacob, C. 2003. Matematika sebagai Komunikasi. Makalah pada Seminar Tingkat Nasional. FPMIPA UPI Bandung. Tidak dipublikasikan

Karli Hilda. 2012. Pembelajaran Tematik untuk Meningkatkan Jiwa Kewirausahaan. Jurnal Pendidikan Penabur, No. 19/Vol. 11/ Hal. 52-63. 
Karlimah. 2010. "Kemampuan Komunikasi dan Pemecahan Masalah Matematis Mahasiswa Pendidikan Guru Sekolah Dasar melalui Pembelajaran Berbasis Masalah". Jurnal Pendidikan, XI (2), 51-60

Lang, H.R., \& Evans, D.N. 2006. Models, Strategis, and Methods for Effective Teaching. USA: Pearson Education, Inc.

Lestari G, Endang \& Maliki, MA. 2003. Komunikasi yang Efektif. Lembaga Administrasi Negara. Jakarta

Mahmud. 2011. Metode Penelitian Pendidikan. Bandung: Pustaka Setia

Meredith, G.G. 2005. The Practice of Entrepreneurship. Genewa: Internasional Labor Organization.

Moleong, Lexy J. 2008. Metode Penelitian Kualitatif. Bandung: Remaja Rosdakarya

Mutadi. 2007. Pendekatan Efektif dalam Pembelajaran Matematika. Jakarta: Pusdikat Tenaga Teknis Keagamaan-Depag bekerjasama dengan DIT Bina Widyaiswara LAN-RI.

National Council of Teacher of Mathematics (NCTM). 2000. Prinsiples and Standards for School Mathematics. USA: Key Curiculum Press.

National Council of Teacher of Mathematics (NCTM). 2003. Program Standards for Initial Preparation of Mathematics Teacher. Standards for Secondary Mathematics Teacher. USA: Key Curiculum Press

Patricia. C. Alcaro, dkk. 2000. Fractions Attack! Children Thinking and Talking Mathematically. Teaching Children Mathematics, Vol. 6, No. 9, Mei 2000, hlm. 562-567.

Pugalee, K David. 2001. Using Communication to Develop Students Mathematical Literacy. Mathematics Teaching in the Middle School. Vol. 6, No. 5, Januari, hlm. 296-299.

Purnawan, Yudi. 2007. Deskripsi Model Pembelajaran Berbasis Proyek. (Online) http://www.yudipurnawan.wordpress.com. [Diakses 5 Januari 2014].

R. Soedjadi. 2000. Kiat Pendidikan Matematika di Indonesia. Jakarta: Proyek Pendidikan Tenaga Akademik, Depdiknas.

Ramsden, P. 2006. Learning to Teach in Higher Education. $2^{\text {nd }}$ ed. New York: Routledge Falmer

Sadirman AM. 2005. Interaksi dan Motivasi Belajar Mengajar. Jakarta: Rajawali Pers.

Suderajat, Hari. 2011. Manajemen Pembelajaran Tematik. Bandung: Sekar Gambir Asri.

Sugiyono. 2011. Metode Penelitian Kuantitatif Kualitatif dan $R \& D$. Bandung: Alfabeta.

Sukmadinata, Nana Syaodih. 2011. Metode Penelitian Pendidikan. Bandung: PT Remaja Rosdakarya Suryana. 2001. Kewirausahaan. Jakarta: Salemba Empat.

Sutama. 2011. Penelitian Tindakan: Teori dan Praktek dalam PTK, PTS, dan PTBK. Surakarta: CV. Citra Mandiri Utama

Wardani, I.G.A.K., dkk. 2003. Penelitian Tindakan Kelas. Jakarta: Pusat Penerbitan Universitas Terbuka.

Wina Sanjaya. 2008. Strategi Pembelajaran Berorientasi Standar Proses Pendidikan. Jakarta: Kencana Prenada Media Group.

Y. Marpaung, dkk. 2010. Gagasan untuk Naskah Akademik Mata Pelajaran Matematika Sekolah Dasar. Jakarta: Kementerian Pendidikan Nasional. Badan Penelitian dan Pengembangan Pusat Kurikulum.

Yamin, Martinis. 2004. Mengembangkan Kompetisi Pebelajar. Jakarta: Universitas Indonesia (UI Press).

Yani, Ramdhani. 2012. Pengembangan Instrumen dan Bahan Ajar untuk Meningkatkan Kemampuan Komunikasi, Penalaran dan Koneksi Mathematis dalam Konsep Integral. Jurnal Penelitian Pendidikan.Vol. 13, No. 1, April 2012 